\title{
ON THE RELATIONSHIP BETWEEN PUBLIC OPINION AND DECISION MAKING IN THE U.S. COURTS OF APPEALS
}

\author{
Bryan Calvin \\ btcalvin@,unt.edu \\ Paul M. Collins, Jr. \\ pmcollins@unt.edu \\ Matthew Eshbaugh-Soha \\ mes@,unt.edu \\ Department of Political Science \\ University of North Texas
}

\begin{abstract}
The potentially undemocratic nature of the federal courts has longed flamed the fires of the debate regarding the proper role of the judiciary in American politics. Extant scholarship concerning the influence of public opinion on judicial decision making focuses almost myopically on the U.S. Supreme Court, neglecting other significant judicial actors. We explore the extent to which the federal courts act as countermajoritarian institutions by investigating the impact of public preferences on decision making in the U.S. Courts of Appeals. Using data from 1961-2002, we examine whether the courts of appeals are influenced by public mood, both indirectly through the federal judicial selection process and directly via responsiveness to changes in circuit and national mood. Our results indicate that public opinion affects courts of appeals decision making indirectly by way of judicial replacements, but we fail to uncover evidence that courts of appeals judges respond directly to changes in public opinion at either the regional or national levels. We conclude that, absent membership turnover, the courts of appeals are not responsive to the will of the public.
\end{abstract}

Paper Prepared for Delivery at the $80^{\text {TH }}$ ANNUAl MeEting of the SOUTHERn Political SCiEnCE Association, NeW Orleans, Louisiana, January 8-10, 2009 
Federal judges occupy a peculiar position in the American political system. Like members of Congress and the president, they have substantial policymaking powers. However, unlike their legislative and executive counterparts, they are not subject to popular will through elections. The electoral independence of the federal courts, coupled with their ability to make public policy (inclusive of the use of judicial review), has long flamed the fires of the debate regarding the proper role of the federal judiciary in the American polity. Scholars are acutely aware of the tension between judges' roles as policymakers and the actuality that federal judges are unelected, positing that the federal courts might operate as countermajoritarian institutions (e.g., Bickel 1962; Dahl 1957; Flemming and Wood 1997; Giles, Blackstone, and Vining 2008; McGuire and Stimson 2004; Mishler and Sheehan 1993; Norpoth and Segal 1994).

Indeed, the fear that a relatively small number of unelected judges can—and do—-substitute their own will for that of duly elected public officials has motivated some to advocate for changes in federal judicial selection, ranging from setting term limits for federal judges (e.g., Calabresi and Lindgren 2006) to calling for their direct election (e.g., Clark 1903). While there are significant normative concerns stemming from the role of federal judges as unelected policymakers (e.g., Comiskey 2009; Friedman 2002), our understanding of the countermajoritarian nature of the federal courts can also be furthered through the empirical analysis of the relationship between public opinion $^{1}$ and judicial making. Simply put, if federal judges are responsive to changes in public opinion, this might mitigate the significance of the fact that these actors are unelected (e.g., Comiskey 2009; Marshall 2008). The purpose of this research is to contribute to the debate

\footnotetext{
${ }^{1}$ We use the terms "public opinion" and "public mood" interchangeably when referring to the mean ideological orientation of the public on a liberal-conservative dimension (e.g., Berry et al. 1998: 327; Stimson 1999: 37).
} 
regarding the undemocratic nature of the federal courts by exploring whether public opinion shapes decision making on the U.S. Courts of Appeals. ${ }^{2}$

An examination of the relationship between public opinion and the decisions courts of appeals judges make is significant for a number of reasons. First, this research contributes to our understanding of the countermajoritarian nature of the federal courts. Although there is a substantial literature devoted to this paradigm, it almost exclusively focuses on the role of the U.S. Supreme Court (but see, e.g., Cook 1977; Kritzer 1979; Manning and Carp 2005; Manning, Kuersten, and Carp 2001; Massie 2002). While the U.S. Supreme Court is a tremendously consequential venue, the almost myopic focus on this institution threatens the generalizability of our understanding of the possible influence of public opinion on judicial decision making. Second, this research is important in that it furthers our understanding of decision making on the courts of appeals. Though the study of these courts has flourished recently (e.g., Benesh 2002; Hettinger, Lindquist, and Martinek 2006; Klein 2002; Songer, Sheehan, and Haire 2000), there are still a host of questions regarding these bodies that demand attention, including these courts' responsiveness to public opinion (Benesh 2002: 141, fn. 63). Further, the fact that the overwhelming majority of appeals in the federal judiciary are terminated in these courts makes the courts of appeals the de facto, if not the de jure, courts of last resort in the federal system (Hettinger, Lindquist, and Martinek 2006: 13). ${ }^{3}$ Put succinctly, the ${ }^{2}$ The U.S. Courts of Appeals are the intermediate appellate courts in the federal judiciary. The thirteen courts of appeals are arranged geographically and enjoy jurisdiction over the gamut of federal appeals emanating from within their circuits, with the exception of the U.S. Court of Appeals for the Federal Circuit, which has nationwide jurisdiction over a subset of specialized cases. ${ }^{3}$ For example, from September 30, 2006 to September 30, 2007, the courts of appeals terminated almost 32,000 cases, while the U.S. Supreme Court disposed of a mere 78 disputes during its 2006 term (Administrative Office of the United States Courts 2007: Tables A-1, S-1). 
significance of understanding these venues in their own right cannot be overstated. Finally, analyzing the possible influence of public mood on courts of appeals decision making is noteworthy since it allows us to examine, not only whether these courts respond to changes in national mood, but also whether these institutions react to changes in regional mood. Because courts of appeals judges are both national and regional actors (e.g., Richardson and Vines 1970; Songer, Sheehan, and Haire 2000), a more nuanced understanding of the relationship between public opinion and judicial decision making is provided by looking at these considerable policymaking venues.

\section{Public Opinion AND The U.S. Courts of Appeals}

The framers of the U.S. Constitution recognized the need for an independent judiciary. To ensure that federal judges were not overly sensitive to the changing will of the public, the Constitution charges the president with appointing federal judges, with the advice and consent of the Senate, and further establishes that Article III judges "shall hold their Offices during good Behavior." In part, the framers' motivation for granting federal judges life tenure and insulating the federal courts from electoral politics stemmed from the recognition that the federal judiciary could serve as a check on efforts by the majority to suppress the interests of unpopular minorities. In addition, the federal courts enjoy the power of judicial review - the ability to declare policies enacted by the elected branches of government unconstitutional. ${ }^{4}$ Through this policymaking power, and those of federal courts more broadly, federal judges are enabled to substitute their judgment for that

${ }^{4}$ Although the origin of judicial review is most commonly associated with the Supreme Court's decision in Marbury v. Madison (1803), Treanor (2005) illustrates that, on a number of occasions, the federal courts declared state and national laws unconstitutional prior to Marbury. Upon their creation by the Evarts Act in 1891, the U.S. Courts of Appeals appeared quite willing to utilize their powers of judicial review. See, e.g., United States v. Carlisle (D.C. Cir. 1895), declaring void provisions of 26 Stat. 583 granting bounty to sugar producers. 
of their elected counterparts on the local, state, and national levels (cf. Whittington 2005). These two features create a significant tension regarding the democratic nature of the federal courts in the American polity.

This tension has certainly not escaped the attention of scholars. Indeed, it is fair to say that there is a veritable cottage industry devoted to examining the countermajoritarian nature of the federal courts. On the one hand, some posit that, because federal judges are not subject to electoral or political accountability as a function of their life tenure, they should not be responsive to changes in public opinion (e.g., Norpoth and Segal 1994; Segal and Spaeth 2002). On the other hand, others argue that federal court judges will be responsive to changes in public mood due to the process by which they are nominated and confirmed, their inability to enforce their decisions, and these judges' everyday interactions with the populace (e.g., Dahl 1957; Epstein and Knight 1998). Below, we outline our expectations for why decision making on the courts of appeals might be influenced by public opinion, both indirectly through the federal judicial selection process and directly through changes in public mood at the national and regional levels.

The first link between public opinion and decision making on the courts of appeals we explore involves the indirect influence of public opinion as it relates to the means by which courts of appeals judges are selected. Like Supreme Court justices, courts of appeals judges are nominated by the president and confirmed by the Senate. As such, through judicial replacements, the legislative and executive branches, reflecting public opinion on the basis of having been elected, select judges who share their ideological orientations (e.g., Dahl 1957; Funston 1975). In other words, federal judges tend to share the ideological preferences of the citizenry because the citizenry elects the federal officials who in turn select federal judges. Moreover, the role of senatorial courtesy in the selection of courts of appeals judges provides for the opportunity for home state senators to have substantial influence on the selection of judges, thus further reinforcing the link between the 
citizenry and courts of appeals judges. Under the norm of senatorial courtesy, senators defer to the preferences of senators from the home state in which there is a judicial vacancy, provided the home state senators share the party affiliation of the president. This compels the president to carefully consider the preferences of home state senators in making judicial appointments to the courts of appeals (e.g., Giles, Hettinger, and Peppers 2001; Songer, Sheehan, and Haire 2000: 155, fn. 1; Wilson 2003). Consistent with this explanation for the indirect influence of public opinion on the decisions of federal court judges, we expect that courts of appeals decision making will be influenced by the preferences of the actors in the federal judicial selection process.

Moving beyond the indirect link between public opinion and courts of appeals decision making, there is reason to believe that federal judges will respond directly to changes in public mood. The first direct link involves a strategic characterization of judicial behavior. With neither the purse nor the sword, the federal courts must rely on the goodwill of the citizenry to follow their decisions and that of the executive branch to enforce those decisions (e.g., Collins 2004: 813; Giles, Blackstone, and Vining 2008; Mishler and Sheehan 1993, 1996; McGuire and Stimson 2004). If the federal courts step too far out of line of public mood, their institutional legitimacy can become threatened, either by a public that does not accept the federal courts' resolution of disputes or by an executive branch that refuses to enforce judicial decisions. Further, courts of appeals judges might also fear that, if they ignore the will of the public, Congress might react by either legislatively overruling judicial decisions or removing the ability of the federal courts to hear certain types of cases through jurisdiction-stripping efforts.

While congressional responses to judicial decisions are most commonly associated with Supreme Court rulings that subvert the will of the public, there are myriad examples of attempts by Congress to exercise its power to rein in the courts of appeals (e.g., Curry 2005; Hooper 2005; Lindquist and Yalof 2001; Redish and Woods 1975; Rotunda 1975; Scott 2004). For example, in 
response to the Ninth Circuit's decision in Newdow v. U.S. Congress ( $9^{\text {th }}$ Cir. 2002), in which the three-judge panel determined that the inclusion of the words "under God" in the Pledge of Allegiance constituted a violation of the First Amendment's prohibition on the establishment of religion, Congress reacted in two ways within six months of the decision. First, Congress passed a law chastising the Ninth Circuit's decision and reaffirming the desirability of the words "under God" in the Pledge. Second, Representative Todd Akin (R-MO) introduced the Pledge Protection Act, which would have stripped the jurisdiction of the federal courts to hear First Amendment challenges to the Pledge of Allegiance (Hooper 2005). ${ }^{5}$ Taken as a whole, the above discussion provides the foundation for a strategic explanation for why the courts of appeals judges might be responsive to public mood. ${ }^{6}$

The second direct link between public mood and courts of appeals decision making involves the possibility that, like other Americans, courts of appeals judges' attitudes might shift, knowingly or not, as public opinion changes (e.g., Epstein and Knight 1998; Giles, Blackstone, and Vining ${ }^{5}$ The Ninth Circuit's decision in Newdow was reversed by the Supreme Court on the grounds that Newdow did not have prudential standing to bring the suit. Although the Supreme Court's majority declined to rule on the constitutionality of the words "under God" in the Pledge, congressional attempts to strip the federal of courts of the jurisdiction to hear such challenges continued (Hooper 2005).

${ }^{6}$ We recognize that courts of appeals judges might also fear reversal by the Supreme Court (e.g., Klein 2002). However, we are unaware of evidence demonstrating that the Supreme Court punishes the courts of appeals, either through a grant of certiorari or through a subsequent reversal, for rendering decisions that are out of line with public opinion. We account for the possible influence of the Supreme Court on courts of appeals decision making in our empirical models through the inclusion of a variable capturing the preferences of the Supreme Court. 
2008; Mishler and Sheehan 1996). This view asserts that courts of appeals judges are susceptible to the influence of public opinion as a function of their everyday interactions with the public. That is, circuit court judges obtain information about public mood in the same manner as other citizensthrough media outlets, such as newspapers, magazines, radio, and television, as well as periodic exchanges with their neighbors (Epstein and Knight 1998: 145). Predating even the legal realists (Tamanaha 2007), this perspective asserts that it is unreasonable to expect judges to shed their personal biases, which may be colored by changes in public opinion, when judges don their black robes to adjudicate legal controversies. The influence of public opinion on judicial decision making might occur unconsciously as judges alter their preferences to reflect those of the public.

Alternatively, judges might consciously follow changes in public mood. Judge LeBaron Colt of the U.S. Court of Appeals for the First Circuit expressed this latter position quite succinctly in a prelegal realist age:

The purpose and end of law are the welfare of society and the happiness of the people. The law should always be viewed from the standpoint of society, and not from the standpoint of the law itself. ...The law is made for society, and not society for the law. The interests of society are primary; the interests of the law secondary. Society is the master, and law its handmaiden. The law must march with society; the constitution must march with the nation (1903: 675).

When theorizing about the direct link between public opinion and decision making on the courts of appeals, it is vital to recognize that circuit court judges are both national and regional actors (Richardson and Vines 1970; Songer, Sheehan, and Haire 2000). On the one hand, circuit court judges are clearly federal officials. Like other high-ranking executive branch appointments, they are confirmed by the Senate. Further, the salaries of courts of appeals judges are appropriated by Congress, most recently under $\$ 225$ of the Federal Salary Act of 1967 . Moreover, in their capacity as federal officials, courts of appeals judges are charged with promoting the consistency of federal 
law. As a means of achieving this goal, courts of appeals judges meet with judges from outside of their circuit at periodic sessions of the Judicial Conference of the United States.

On the other hand, courts of appeals judges are regional actors. The precedents of circuit courts are only binding on federal district courts and other courts of appeals panels within the circuit (e.g., Klein 2002: 5). Furthermore, their jurisdiction is geographical, meaning that the courts of appeals can only hear cases arising within their circuit. Carp (1972: 407) describes the regional nature of the courts of appeals concisely in noting that "the circuit is a semi-closed system, a nearly selfcontained organizational unit within which there is considerable interaction among its members and almost no interaction between the members of one unit (circuit) and another" (see also Howard 1981). Moreover, the reality that courts of appeals judges are regional decision makers has not escaped the attention of Congress. In addition to the norm of senatorial courtesy discussed above, which gives home state senators substantial input with regard to the selection of courts of appeals judges, 28 U.S.C.A. $\$ 44$ requires that, with the exception of the District of Columbia Circuit, courts of appeals judges must be residents of their circuits and further provides for the representation of at least one judge from each state in the circuit. Even without this statutory requirement, the fact remains that courts of appeals judges are products of their circuits. Courts of appeals judges are overwhelmingly born and raised within their circuits, the majority have attended law school within their circuits, and most have been employed in their circuits prior to their ascension to the courts of appeals (Gryski and Zuk 2009; Richardson and Vines 1970: 72). Additionally, courts of appeals judges are prominent members of their local communities, participating in a wide range of civic and political activities that enable them to keep in touch with the cultural norms and mood of the regional public (e.g., Slotnick 1984).

The reality that courts of appeals judges operate as both national and regional actors suggests that these judges might be influenced by both national and circuit-level public mood. First, in their 
capacity as federal officials, we expect they will be susceptible to the influence of national mood.

Inasmuch as courts of appeals judges are charged with promoting the coherency of federal law, they should be particularly in tune with the will of the American citizenry to ensure that federal law, and its interpretation, represents the mood of the public as a whole. Second, in their role as regional actors, we expect that courts of appeals judges will be responsive to changes in circuit-level opinion. Circuit court judges are required to live within the circuits on which they serve, which augments their ability to keep in touch with circuit-level public opinion. Further, since their opinions are only binding law within their own circuits, this enhances the importance of rendering decisions that do not step too far out of line with the mood of the circuit. Accordingly, we examine whether both national and circuit-level public opinion shapes decision making on the courts of appeals.

\section{DATA AND METHODOLOGY}

In order to determine whether public opinion influences decision making on the U.S. Courts of Appeals, we utilize data on these courts' decisions extracted from the Songer (2009) and Kuersten and Haire (2009) databases. The merger of these databases allows us to examine the influence of public opinion on the courts of appeals from 1961-2002. ${ }^{7}$ Each of these datasets contains information on a random sample of 30 cases per year from each of the courts of appeals, with the exception of the Federal Circuit. ${ }^{8}$ Because we lack measures of public opinion for the District of Columbia Circuit, we exclude this circuit from our empirical models. As such, our dataset contains

${ }^{7}$ While the Songer (2009) database contains information on courts of appeals decisions dating to 1925, because our measures of public opinion begin in 1960, and because we employ a one year lag of public opinion (discussed below), we analyze the 1961-2002 time period.

${ }^{8}$ Due to missing information in the Songer (2009) and Kuersten and Haire (2009) databases on the ideological direction of the courts of appeals' decisions, our data contain an average of 25.2 cases per circuit-year. 
information on the decision making patterns of the First through Tenth Circuits from 1961-2002 and for the Eleventh Circuit from 1982, the first full year it was in operation, through 2002. To maximize the information on the decision making proclivities of the circuits under analysis, we include cases heard by both three-judge panels and en banc panels.

The unit of analysis in our data is the circuit-year. Our dependent variable measures the percentage of liberal decisions rendered by each circuit per year, as identified in the Songer (2009) and Kuersten and Haire (2009) databases. For cases involving the rights of the criminally accused, a liberal decision favors the criminal defendant, while a conservative decision favors the government. In the realm of civil rights and liberties, a liberal decision favors the litigant claiming a violation of its civil rights or liberties, while a conservative decision supports restrictions on those rights or liberties. For cases involving economic activity, a liberal decision favors the interests of labor, the government, or the economic underdog, while a conservative decision is pro-business.

The cross-sectional and time series components of our dataset suggest that we employ fixed effects panel data time series analysis techniques. ${ }^{10}$ However, fixed effects regression models are incapable of accounting for the sampling composition of the Kuersten and Haire (2009) and Songer (2009) databases. Given this, we report the results of two model specifications. First, we pool all observations and use an Ordinary Least Squares (OLS) regression model, which enables us to

\footnotetext{
${ }^{9}$ To ensure the robustness of our results in light of the decision to include en banc cases, we ran our empirical models excluding en banc panels, the results of which are consistent with those reported here.

${ }^{10}$ We have also explored the use of a random effects regression model and determined that it was inappropriate for our data based on a statistically significant Breusch-Pagan test which indicates that the fixed effects model is felicitous given that that there are no time-specific effects for these data
} (Baltagi 2008: 70). 
include the weights reported in the Kuersten and Haire (2009) and Songer (2009) databases. Second, we use a fixed-effects regression model that does not account for the sampling composition of our data. Significantly, the nearly identical results regardless of model specification (i.e., OLS versus fixed effects regression) corroborates the robustness of our findings and further indicates that there are no time-specific effects influencing the relationships between the independent and dependent variables in the models. What is more, neither autocorrelation nor heteroskedasticity are present in the OLS model, suggesting that there is no need to employ Generalized Least Squares estimates.

As noted above, there are two primary paths by which the courts of appeals might be influenced by public opinion: indirectly through the federal judicial selection process (e.g., Dahl 1957) and directly via responsiveness to contemporary changes in public opinion (e.g., Mishler and Sheehan 1993). To operationalize the indirect influence of public opinion, we include a Circuit Preferences variable that measures the ideology of the median judge serving on each circuit, based on the Giles, Hettinger, and Peppers (2001) scores. These scores are particularly suitable for capturing the indirect influence of public opinion in that they account for the dynamics of the federal judicial selection process as it relates to the role of senatorial courtesy. When neither of the home state senators share the president's party affiliation, the judge is assigned the president's Common Space score (Poole 1998). When only one of the home state senators is a member of the president's political party, the judge is given that senator's Common Space score. If both of the home state senators share the president's party affiliation, the judge is assigned the mean of the two senators' Common Space scores. Because higher values correspond to more conservative judges, if there is an indirect influence of public opinion on courts of appeals decision making, we expect this variable will be negatively signed.

To operationalize the direct influence of public opinion, we include two variables based on Berry et al.'s $(1998,2007)$ state-level indicators of public mood. Berry et al. calculate yearly public 
mood for each of the American states using four facets of information: interest group ratings of a state's congressional delegation, estimated ideology scores of the incumbent congresspersons' challengers, election results that reflect the ideological cleavages in the state electorate, and the size of the congressional districts in the state. We have opted to use the Berry et al. measure, as opposed to alternative proxies for state-level public opinion (e.g., Brace et al. 2004; Erikson, Wright, and McIver 1993), for three reasons. First, the Berry et al. measure most closely approximates public mood, the concept of which has been directly linked to examining the relationship between public opinion and policy outputs (e.g., Stimson 1999), including those of courts (e.g., Flemming and Wood 1997; McGuire and Stimson 2004; Mishler and Sheehan 1993, 1996; Norpoth and Segal 1994). In other words, the Berry et al. measure captures policy mood, as compared to symbolic ideology (e.g., Berry et al. 2007: 124), which is represented by measures of ideology that rely on survey respondents' self-identifications as to their political orientations and have been most closely linked to policy attitudes rather than policy outputs (e.g., Brace et al. 2004; Erikson, Wright, and McIver 1993). ${ }^{11}$ Second, because Berry et al. calculate public mood using the American state as the level of analysis, we can easily aggregate state-level opinion to the circuit and national levels, thus providing tests for whether courts of appeals are responsive to both regional (i.e., circuit-level) and national changes in public opinion based on the same metric (e.g., Berry et al. 2007: 124-125). Finally, the Berry et al. measure is desirable since it provides annual estimates of the policy moods of each of the American states for a substantially longer period of time than other common measures

${ }^{11}$ To illustrate, Berry et al. (2007: 125) compare biannual "national" versions of the state-level measures of public opinion discussed above to Stimson's (1999) national estimate of public mood from 1976-1998. They find that the Berry et al. measure correlates with Stimson's public mood index at 0.85 , far exceeding the correlations for the other measures tested, which range from -0.26 to 0.18 . 
of state-level public opinion, thus maximizing our ability to conduct a longitudinal analysis of the relationship between public opinion and decision making on the courts of appeals. ${ }^{12}$

Our first variable, Circuit Mood, captures public mood at the circuit level. This variable is based the population weighted circuit-level aggregation of Berry et al.'s (1998, 2007) state-level indicators of public mood, lagged one year. Since higher scores on this variable correspond to liberal policy moods, we expect this variable will be positively signed. Our second variable, National Mood, captures public mood at the national level. This variable is based on the population weighted national-level aggregation of Berry et al.'s $(1998,2007)$ state-level proxies for public mood, lagged one year. ${ }^{13}$ If courts of appeals judges respond to changes in national public mood, we expect this variable will be positively signed. We have lagged our mood variables in order to avoid contaminating our empirical results from the decision to measure courts of appeals policy outputs that come partially before and partially after changes in public mood, which are measured on an annual basis (e.g., McGuire and Stimson 2004: 1028). Thus, while we acknowledge that is theoretically appropriate to expect courts of appeals judges to respond to contemporaneous public mood, we believe it makes good empirical sense to lag our mood variables by one year to control for the temporal relationship between public mood and decision making on the courts of appeals. ${ }^{14}$

${ }^{12}$ For an illuminating discussion of the limitations of various measures of state-level public opinion, see the symposium on measuring state citizen ideology in issue 2 of volume 7 of State Politics and Policy Quarterly.

${ }^{13}$ As an alternative to our National Mood variable, we ran an auxiliary analysis replacing this measure for Stimson's (1999) national public mood index, the results of which corroborate those reported here.

${ }^{14}$ We obtain substantively identical results when we employ contemporaneous measures of public mood. 
While the primary purpose of this paper is to explore the relationship between public opinion and courts of appeals decision making, we are cognizant of the need to control for other factors that might shape the decision making patterns of courts of appeals judges, in addition to including variables that allow us to more closely parse out the influence of public mood. Above, we have posited that the courts of appeals might be shaped by public opinion because, should these courts step too far out of line with public opinion, Congress might retaliate by overriding courts of appeals decisions or stripping these courts of their jurisdiction to hear certain types of cases. Likewise, the president might react by indifferently enforcing courts of appeals decisions. In order to more closely parse out the causal process by which courts of appeals might respond to public mood, it is necessary to control for the preferences of these actors. Accordingly, we include a Congressional Preferences variable, which is composed of the Common Space score (Poole 1998) of the median member of Congress. We also include a measure of Presidential Preferences, which represents the Common Space score of the president. Since higher scores on these variables indicate more conservative ideologies, if the courts of appeals are constrained by their elected counterparts, we expect these variables will be negatively signed.

We account for the courts of appeals' place in the judicial hierarchy by including a Supreme Court Preferences variable. This variable takes on the Judicial Common Space score of the median justice on the Supreme Court and is thus based on the same metric as our Circuit Preferences variable (Epstein et al. 2007), as well as the variables capturing the preferences of Congress and the president. Because higher values correspond to more conservative Supreme Courts, if the Supreme Court is capable of constraining the decision making of courts of appeals panels, we expect this variable will be negatively signed.

We control for fact that the courts of appeals overwhelmingly affirm criminal appeals, resulting in conservative outcomes (e.g., Howard 1981). While these cases are extremely important 
to the individual appealing his or her conviction, from the standpoint of the courts of appeals they tend to raise legally inconsequential issues resulting in a lack of judicial support, but nonetheless must be heard due to the courts of appeals' mandatory jurisdiction. To capture the reality that the courts of appeals under analysis varied with respect to the number of criminal appeals decided, both over time and in comparison to one another, we include a Percentage of Criminal Cases variable that represents the percentage of all cases under analysis involving criminal appeals, per circuit-year. Because of the courts of appeals' prodigious tendency to affirm these appeals, resulting in conservative outcomes given the coding of our dependent variable, we expect that this variable will be negatively signed, indicating that a court of appeals with a relatively large criminal docket will render more conservative decisions than a court of appeals with a smaller criminal docket.

Finally, in the OLS regression model, we include dummy variables for each circuit in the data, save one, in order to account for circuit-specific differences that might be attributable to regional norms and further differences in the courts of appeals' dockets that might shape judicial decision making. ${ }^{15}$ The inclusion of these circuit dummies also allows us to isolate the effects of circuit-level public opinion given the pooled nature of our data thus reducing possible bias in our results (e.g., Green, Kim, and Yoon 2001).

\section{EMPIRICAL RESULTS}

Table 1 reports the results of the OLS and fixed effects regression models that estimate influences on the percentage of liberal decisions handed by each circuit per year. ${ }^{16}$ The OLS regression model includes dummy variables for each of the circuits, save one, enabling us to utilize

${ }^{15}$ Circuit-specific differences are accounted for in the fixed effects regression model in that circuits are the panel variables and years are the temporal variables.

${ }^{16}$ There is slight collinearity between the Presidential Preferences and Supreme Court Preferences variables $(r$ $=0.36$, but this does not influence the results. 
the weights reported in the Kuersten and Haire (2009) and Songer (2009) databases and to simulate a fixed effects regression model. An F-test for the OLS regression model confirms that the unrestricted model (with circuit dummy variables) is apposite, indicating that the model is influenced by variation at the circuit-level $(\mathrm{F}=4.0, \mathrm{p}<.01)$. This is further substantiated by the statistically significant F-test for the fixed effects model $(\mathrm{F}=2.63, \mathrm{p}<.01)$. Thus, both sets of statistics corroborate that the circuit-level indicators are jointly significant and if we were to exclude them from the OLS regression model, the results would be biased and inconsistent. Because the direction, significance, and magnitude of the coefficients of the independent variables are virtually indistinguishable regardless of whether we employ an OLS regression model or a fixed effects regression model, for the sake of parsimony we interpret the results of the OLS regression model.

\section{[Table 1 About Here]}

Table 1 assesses both the indirect and direct effects of public opinion on courts of appeals decision making. Recall that the indirect linkage hypothesis posits that voters elect presidents and senators who share their ideological preferences, who in turn appoint and confirm federal judges who share their own preferences. This argument is tested via the Circuit Preferences variable. The relationship, as evidenced by the statistically significant and negative Circuit Preferences coefficient is as hypothesized: as the ideology of the circuit becomes more conservative, the percentage of liberal decisions declines. More substantively, a one standard deviation increase in the conservatism of the circuit corresponds to $4.1 \%$ decrease in liberal decisions by circuit-year. In short, Table 1 provides strong evidence that public opinion influences courts of appeals decisions indirectly through the federal judicial selection process.

The direct effects of public opinion on courts of appeals decision making are captured through the national (National Mood) and circuit-level (Circuit Mood) indicators of public mood. Table 1 reveals that neither of the direct measures of public mood achieves statistical significance, leaving 
us to conclude that courts of appeals judges are not influenced directly by public preferences. These findings not only contrast with our theoretical expectations for the responsiveness of the courts of appeals to public mood, they are also distinct from recent research indicating that the Supreme Court is directly responsive to public mood (e.g., Flemming and Wood 1997; Giles, Blackstone, and Vining 2008; McGuire and Stimson 2004). This suggests that the mechanisms that influence the decision making of justices on the Supreme Court are different from those that influence judicial choice on the U.S. Courts of Appeals (e.g., Martinek 2009).

Turning now to the control variables, we find that only one of the variables capturing the ideology of the national institutions we control for achieves statistical significance. That is, the Congressional Preferences variable indicates that Congress is capable of constraining courts of appeals decision making: as Congress becomes more conservative, the percentage of liberal cases decided by the U.S. Courts of Appeals declines. ${ }^{17}$ More specifically, a one standard deviation increase in the conservatism of the median member of Congress corresponds to a $1.4 \%$ decrease in the percentage of liberal decisions rendered by the courts of appeals. ${ }^{18}$ While the magnitude of this impact is relatively modest compared to the influence of the federal judicial selection process, this is nonetheless an important finding. Although the courts of appeals are less visible than the U.S.

${ }^{17}$ To be sure, the Congressional Preferences variable captures a very different phenomena than the Circuit Preferences variable, which accounts for the actors in the federal judicial selection process. In fact, the correlation between these two variables is an anemic 0.14 .

${ }^{18}$ While multicollinearity precludes us from jointly including variables representing the Common Space scores of the median members of the House and Senate, when we replace the Congressional Preferences variable with variables capturing the ideology of the median members of the House and Senate in separate model specifications, we obtain similar results, statistically and substantively, in both the OLS and fixed effects regression models. 
Supreme Court, they are certainly not immune from congressional actions that can potentially weaken their institutional legitimacy and it appears that courts of appeals judges consider the possibility of congressional responses when rendering their decisions, thus supporting a strategic characterization of judicial behavior. Moreover, this is a particularly interesting finding in that it indicates an often overlooked indirect link between public opinion and judicial decision making. That is, since Congress is capable of shaping decision making on the courts of appeals, and since the public elects members of Congress, this suggests that the direct election of members of Congress provides an additional indirect link between public opinion and courts of appeals decision making. Considered collectively with the results of the variables capturing the direct and indirect influences of public mood, these findings indicate that, in the absence of membership turnover, either on the courts of appeals or in Congress, the courts of appeals are not responsive to the will of the public.

The final control variable captures the percentage of criminal cases rendered by each circuit, per year, in the data. This variable has a negative and statistically significant impact on circuit court liberalism, indicating that circuits with larger criminal dockets tend to render more conservative decisions. Substantively, a 10\% increase in a court's criminal docket leads to a $3.4 \%$ decrease in the percentage of cases decided in a liberal direction. This corroborates extant research indicating that the vast majority of criminal cases are affirmed by the courts of appeals, resulting in conservative outcomes (e.g., Howard 1981).

\section{CONCLUSIONS}

Political and legal scholars have long been attentive to the peculiar role occupied by federal court judges. Though unelected, these judges have substantial policy making powers and thus can potentially behave as countermajoritarian actors, substituting their own wills for that of their duly elected counterparts. This reality has motivated scholars to investigate the extent to which public

opinion might influence judicial choice. While there is a voluminous body of scholarship devoted to 
this paradigm, it is overwhelmingly focused on the U.S. Supreme Court. This paper makes a notable contribution to the literature on judicial responsiveness to public opinion by investigating the mechanisms by which public opinion shapes decision making on the U.S. Courts of Appeals.

We have provided strong evidence that public opinion indirectly influences courts of appeals judges through the federal judicial selection process. The public elects presidents and senators who work together in the selection of courts of appeals judges who share their ideological preferences. Through this mechanism, the public's preferences are indirectly transferred to the courts of appeals. Although this link between public mood and the courts of appeals is only indirect, it is vital to recognize that public opinion is regularly transmitted to the courts of appeals via judicial replacements. During the time period under analysis here (1961-2002), presidents have successfully appointed an average of 9 courts of appeals judges per year (Gryski and Zuk 2009). As this figure indicates, presidents, with the advice and consent of the Senate, have the substantial capacity to shape the ideological tenor of the courts of appeals in a manner that is commensurate with the will of the electorate.

Our results failed to provide evidence that courts of appeals judges respond directly to changes in public mood, whether measured at the circuit or national level. While we expected to find that courts of appeals judges respond to changes in public mood, the null results are not altogether unsurprising. Though the U.S. Courts of Appeals are enormously consequential venues, acting as the de facto courts of last resort in the federal judiciary (Hettinger, Lindquist, and Martinek 2006: 13), the fact remains that they are not highly visible institutions. Not only are the courts of appeals among the least understood courts in the federal system, they are also one of the least conspicuous (e.g., Howard 1981; Martinek 2009). Songer, Sheehan, and Haire (2000: xiii) articulate this point in no uncertain terms: "the courts of appeals exist at the very edge of the average American's consciousness if at all." Because the courts of appeals are not on the radar of the American citizenry, 
it is arguably unreasonable to expect judges to genuinely fear that the institutional legitimacy of the courts of appeals will be threatened if decisions subvert the will of the citizenry. Simply put, if the public is largely unaware of the day to day business of the courts of appeals, there is little reason to believe that the public will react negatively by failing to comply with circuit court decisions, should these courts step too far out of line from public mood.

Though the citizenry is largely unaware of the courts of appeals, it is clear that these courts occasionally capture the attention of the national media, thus raising their profiles in the eyes of the public. Highly salient decisions, such as the aforementioned Pledge of Allegiance case, are undoubtedly capable of attracting the eyes of the American public. If concerns about institutional legitimacy and compliance are real for courts of appeals judges, we might expect public opinion to influence itself most strongly in particularly salient cases (e.g., Giles, Blackstone, and Vining 2008). While the current research cannot speak to this possibility, analyzing the influence of public opinion in salient and non-salient cases will be a fruitful avenue for future research. We also encourage researchers to address whether the courts of appeals are influenced by public opinion in particular issue areas, which will provide a more nuanced view of the undemocratic nature of these courts. ${ }^{19}$

${ }^{19}$ In making these statements, it is important to recognize that the Kuersten and Haire (2009) and Songer (2009) databases alone are likely not appropriate for tackling these questions. That is, while the random sampling composition of these datasets is capable of providing a generalizable investigation into the influence of public opinion on courts of appeals decision making, the fact that each circuit is represented by 30 cases per year suggests that parsing out cases on the basis of their salient or non-salient nature, and issue area, will result in too small a number of cases from each circuit to generalize findings in meaningful ways. Accordingly, future research devoted to this question will be best served by augmenting these databases with additional cases. 
In addition to our central focus on examining the primary direct and indirect influences of public opinion on judicial decision making, we have also demonstrated that the ideological preferences of Congress shape judicial choice on the courts of appeals, thus providing evidence of a second indirect link between public opinion and judicial decision making. While our purpose in exploring this relationship was primarily to more thoroughly parse out the causal mechanisms by which public mood might influence the courts of appeals, this finding is noteworthy in its own right as it corroborates strategic characterizations of judicial choice. Given that we have provided preliminary support that Congress can constrain the courts of appeals, we encourage future researchers to explore the mechanisms by which courts of appeals judges might fear retaliation by Congress and the circumstances under which Congress can most effectively constrain the circuit courts. Taken as a whole, we envision this research as an important first step at better understanding the countermajoritarian nature of these highly significant policy making venues and we are certain that future research on the democratic nature of the U.S. Courts of Appeals will contribute to our comprehension of the politics of judicial choice. 


\section{REFERENCES}

Administrative Office of the United States Courts. 2007. Judicial Business of the United States Courts: Annual Report of the Director. Washington: U.S. Government Printing Office.

Baltagi, Badi H. 2008. Econometric Analysis of Panel Data. $4^{\text {th }}$ ed. Chichester, UK: John Wiley \& Sons.

Benesh, Sara C. 2002. The U.S. Court of Appeals and the Law of Confessions: Perspectives on the Hierarchy of Justice. New York: LFB Scholarly Publishing.

Berry, William D., Evan J. Ringquist, Richard C. Fording, and Russell L. Hanson. 1998. "Measuring Citizen and Government Ideology in the American States, 1960-1993." American Journal of Political Science 42(1): 327-348.

Berry, William D., Evan J. Ringquist, Richard C. Fording, and Russell L. Hanson. 2007. "The Measurement and Stability of State Citizen Ideology." State Politics and Policy Quarterly 7(2): 111-132.

Bickel, Alexander M. 1962. The Least Dangerous Branch: The Supreme Court at the Bar of Politics. Indianapolis: Bobbs-Merrill.

Brace, Paul, Kevin Arceneaux, Martin Johnson, and Stacy G. Ulbig. 2004. "Does State Political Ideology Change over Time?” Political Research Quarterly 57(4): 529-540.

Calabresi, Steven G., and James Lindgren. 2006. "Term Limits for the Supreme Court: Life Tenure Reconsidered." Harvard Journal of Law and Public Policy 29(3): 769-877.

Carp, Robert A. 1972. "The Scope and Function of Intra-Circuit Judicial Communication: A Case Study of the Eighth Circuit." Law and Society Review 6(3): 405-426.

Clark, Walter. 1903. “Law and Human Progress.” American Law Review 37(4): 512-529.

Collins, Paul M., Jr. 2004. "Friends of the Court: Examining the Influence of Amicus Curiae Participation in U.S. Supreme Court Litigation." Law and Society Review 38(4): 807-832.

Colt, LeBaron B. 1903. "Law and Reasonableness.” American Law Review 37(5): 657-676.

Comiskey, Michael. 2009. "Is There Really a Countermajoritarian Problem?” In Exploring Judicial Politics, ed. Mark C. Miller. New York: Oxford University Press.

Cook, Beverly B. 1977. "Public Opinion and Federal Judicial Policy." American Journal of Political Science 21(3): 567-600.

Curry, Brett W. 2005. “The Courts, Congress, and the Politics of Federal Jurisdiction.” Ph.D. diss. Ohio State University.

Dahl, Robert A. 1957. "Decision-Making in a Democracy: The Supreme Court as a National PolicyMaker." Journal of Public Law 6(2): 279-295. 
Epstein, Lee, and Jack Knight. 1998. The Choices Justices Make. Washington: CQ Press.

Epstein, Lee, Andrew D. Martin, Jeffrey A. Segal, and Chad Westerland. 2007. "The Judicial Common Space.” Journal of Law, Economics, and Organization 23(2): 303-325.

Erikson, Robert S., Gerald C. Wright, Jr., and John P. McIver. 1993. Statehouse Democracy: Public Opinion and Policy in the American States. New York: Cambridge University Press.

Flemming, Roy B., and B. Dan Wood. 1997. "The Public and the Supreme Court: Individual Justice Responsiveness to American Policy Moods." American Journal of Political Science 41(2): 468-498.

Friedman, Barry. 2002. "The Birth of an Academic Obsession: The History of the Countermajoritarian Difficulty." Yale Law Journal 112(2): 153-259.

Funston, Richard. 1975. "The Supreme Court and Critical Elections." American Political Science Review 69(3): 795-811.

Giles, Micheal W., Bethany Blackstone, and Richard L. Vining, Jr. 2008. “The Supreme Court in American Democracy: Unraveling the Linkages between Public Opinion and Judicial Decision Making." Journal of Politics 70(2): 293-306.

Giles, Micheal W., Virginia A. Hettinger, and Todd Peppers. 2001. "Picking Federal Judges: A Note on Policy and Partisan Selection Agendas.” Political Research Quarterly 54(3): 623-641.

Green, Donald P., Soo Yeon Kim, and David H. Yoon. 2001. "Dirty Pool.” International Organization 55(2): 441-468.

Gryski, Gerard S., and Gary Zuk. 2009. A Multi-User Data Base on the Attributes of U.S. Appeals Court Judges, 1801-2004. Department of Political Science, Auburn University. Available at: http://www.cas.sc.edu/poli/juri/auburndata.htm.

Hettinger, Virginia A., Stefanie A. Lindquist, and Wendy L. Martinek. 2006. Judging on a Collegial Court: Influences on Federal Appellate Decision Making. Charlottesville: University of Virginia Press.

Hooper, Alexander K. 2005. "Jurisdiction-Stripping: The Pledge Protection Act of 2004." Harvard Journal on Legislation 42(2): 511-523.

Howard, J. Woodford, Jr. 1981. Courts of Appeals in the Federal Judicial System: A Study of the Second, Fifth, and District of Columbia Circuits. Princeton: Princeton University Press.

Klein, David E. 2002. Making Law in the United States Courts of Appeals. New York: Cambridge University Press.

Kritzer, Herbert M. 1979. "Federal Judges and Their Political Environments: The Influence of Public Opinion.” American Journal of Political Science 23(1): 194-207. 
Kuersten, Ashlyn K., and Susan B. Haire. 2009. Update to the Appeals Court Data Base (1997-2002). Department of Political Science, Western Michigan University. Available at: http://www.cas.sc.edu/poli/juri/appctdata.htm.

Lindquist, Stefanie A., and David A. Yalof. 2001. "Congressional Responses to Federal Circuit Court Decisions.” Judicature 85(2): 61-68.

Manning, Kenneth L., and Robert A. Carp. 2005. "Judicial Decision-Making and Public Opinion: A State Level View." Presented at the Annual Meeting of the Midwest Political Science Association, Chicago.

Manning, Kenneth L., Ashyln Kuersten, and Robert A. Carp. 2001. "Public Opinion, Political Context, and Decision-Making in the Lower Federal Courts." Presented at the Annual Meeting of the American Political Science Association, San Francisco.

Marbury v. Madison, 5 U.S. 137 (1803).

Marshall, Thomas R. 2008. Public Opinion and the Rehnquist Court. Albany: State University of New York Press.

Martinek, Wendy L. 2009. "Appellate Workhorses of the Federal Judiciary: The U.S. Courts of Appeals.” In Exploring Judicial Politics, ed. Mark C. Miller. New York: Oxford University Press.

Massie, Tajuana. 2002. "Public Opinion and the U.S. Courts of Appeals: A Cross-Sectional Time Series Model of External Influences on Ideological Changes in Courts of Appeals Decisions." Presented at the Annual Meeting of the American Political Science Association, Boston.

McGuire, Kevin T., and James A. Stimson. 2004. "The Least Dangerous Branch Revisited: New Evidence on Supreme Court Responsiveness to Public Preferences." Journal of Politics 66(4): 10181035.

Mishler, William, and Reginald S. Sheehan. 1993. "The Supreme Court as a Countermajoritarian Institution? The Impact of Public Opinion on Supreme Court Decisions." American Political Science Review 87(1): 87-101.

Mishler, William, and Reginald S. Sheehan. 1996. "Public Opinion, the Attitudinal Model, and Supreme Court Decision Making: A Micro-Analytic Perspective." Journal of Politics 58(1): 169-200.

Newdow v. U.S. Congress, 292 F.3d 597 (9th Cir. 2002).

Norpoth, Helmut, and Jeffrey A. Segal. 1994. "Comment: Popular Influence on Supreme Court Decisions.” American Political Science Review 88(3): 711-716.

Poole, Keith T. 1998. "Recovering a Basic Space from a Set of Issue Scales." American Journal of Political Science 42(3): 954-993. 
Redish, Martin H., and Curtis E. Woods. 1975. "Congressional Power to Control the Jurisdiction of Lower Federal Courts: A Critical Review and New Synthesis." University of Pennsylvania Law Review 124(1): 45-109.

Richardson, Richard J., and Kenneth N. Vines. 1970. The Politics of Federal Courts: Lower Courts in the United States. Boston: Little, Brown.

Rotunda, Ronald D. 1975. "Congressional Power to Restrict the Jurisdiction of the Lower Federal Courts and the Problem of School Busing." Georgetown Law Journal 64(4): 839-867.

Scott, Kevin M. 2004. "Time for a Divorce? Splitting the Ninth Circuit Court of Appeals." Presented at the Annual Meeting of the Midwest Political Science Association, Chicago.

Segal, Jeffrey A., and Harold J. Spaeth. 2002. The Supreme Court and the Attitudinal Model Revisited. New York: Cambridge University Press.

Slotnick, Elliot E. 1984. "The Paths to the Federal Bench: Gender, Race, and Judicial Recruitment Variation." Judicature 67(8): 371-388.

Songer, Donald R. 2009. The United States Courts of Appeals Data Base. Columbia, SC: Department of Political Science, University of South Carolina. Available at:

http://www.cas.sc.edu/poli/juri/appctdata.htm.

Songer, Donald R., Reginald S. Sheehan, and Susan B. Haire. 2000. Continuity and Change on the United States Courts of Appeals. Ann Arbor: University of Michigan Press.

Stimson, James A. 1999. Public Opinion in America: Moods, Cycles, and Swings. $2^{\text {nd }}$ ed. Boulder: Westview.

Tamanaha, Brian Z. 2007. “The Realism of the 'Formalist' Age." St. John's Legal Studies Research Paper No. 06-0073. Available at SSRN: $\underline{\text { http://ssrn.com/abstract }=985083}$.

Treanor, William M. 2005. “Judicial Review Before Marbury.” Stanford Law Review 58(2): 455-562.

United States v. Carlisle, 5 App. D.C. 138 (D.C. Cir. 1895).

Whittington, Keith E. 2005. "'Interpose Your Friendly Hand': Political Supports for the Exercise of Judicial Review by the United States Supreme Court.” American Political Science Review 99(4): 583-596.

Wilson, Sarah. 2003. "Appellate Judicial Appointments During the Clinton Presidency: An Inside Perspective." Journal of Appellate Practice and Process 5(1): 29-47. 
Table 1. The Influence of Public Opinion on Courts of Appeals Decision Making, 1961-2002

\begin{tabular}{|c|c|c|}
\hline Variable & OLS Regression & Fixed Effects Regression \\
\hline \multicolumn{3}{|l|}{ Indirect Influence } \\
\hline Circuit Preferences [-] & $-16.33(2.79)^{*}$ & $-15.15(3.62)^{*}$ \\
\hline \multicolumn{3}{|l|}{ Direct Influence } \\
\hline Circuit Mood [+] & $-0.05(0.16)$ & $-0.14(0.14)$ \\
\hline National Mood [+] & $0.12(0.24)$ & $0.19(0.21)$ \\
\hline \multicolumn{3}{|l|}{ Controls } \\
\hline Congressional Preferences [-] & $-19.88(5.18)^{*}$ & $-17.06(4.45)^{*}$ \\
\hline Presidential Preferences [-] & $1.08(1.20)$ & $1.56(0.73)$ \\
\hline Supreme Court Preferences [-] & $-1.46(4.23)$ & $-0.02(3.60)$ \\
\hline Percentage of Criminal Cases [-] & $-0.34(0.05)^{*}$ & $-0.32(0.06)^{*}$ \\
\hline Constant & $49.90(9.36)^{*}$ & $47.27(9.15)^{*}$ \\
\hline R-squared & .32 & .23 \\
\hline F-test & $11.94 *$ & $18.73^{*}$ \\
\hline Breusch-Pagan Heteroskedasticity Test ${ }^{\mathrm{a}}$ & 17.91 & \\
\hline Breusch-Pagan Fixed Effects Test ${ }^{\mathrm{b}}$ & & $22.20^{*}$ \\
\hline $\mathrm{N}$ & 430 & 430 \\
\hline \multicolumn{3}{|c|}{$\begin{array}{l}\text { The unit of analysis is the circuit-year. The dependent variable is the percentage of courts of appeals } \\
\text { decisions decided in the liberal direction. Entries in parentheses are robust standard errors. The } \\
\text { expected direction of the parameter estimates of the independent variables appear in brackets. The } \\
\text { OLS model includes } 10 \text { circuit dummy variables to control for circuit-level effects (results not } \\
\text { shown). The data in the OLS model are weighted to account for the sampling composition of the } \\
\text { Kuersten and Haire (2009) and Songer (2009) databases. The Durbin Watson test (1.62) for the } \\
\text { fixed effects model falls into the zone of indifference, although by only a few one-hundredths of a } \\
\text { point. We report the non-corrected coefficients and note that there are no substantive differences in } \\
\text { the fixed effects, AR1 model. } \\
{ }^{a} \text { A statistically insignificant Breusch-Pagan test indicates that heteroskedasticity is not present in the } \\
\text { data. } \\
\text { b A statistically significant Breusch-Pagan test indicates that a fixed effects model is appropriate and } \\
\text { that there are no time-specific effects in the data (Baltagi 2008: 70). } \\
* \text { p }<.05 \text { (two-tailed test). }\end{array}$} \\
\hline
\end{tabular}

